○冨山道夫（水原郷病院）

1.はばめに

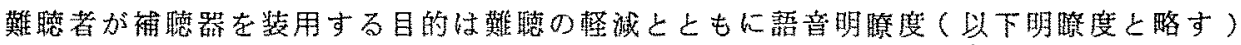
の改善にあり、このための補聴器適合方法がいくつか提唱されているっ。う基礎となるの は正常聴力者を対象としたフィルター語音による検查であり、低周波数带域の增幅と有声子 音、亶音群の明瞭度、 $4000 \mathrm{~Hz}$ 以上の高周波数帯域の增幅と刑声子音群の明瞭度は相関するこ とが報告されている ${ }^{2)}$ 。しかしフィルタ一語意による明瞭度の分析結果がそのまま難㯖者 に適応されるかどうかは種々の意見があり゙、実際に補聴器装用者を対象として明瞭度の改 善を目的とした補聴器谪合方法を検討する必要がある。そこで今回は裸耳明瞭度が良好て 補聴器が日常生活に適合した症例を対象として、実耳聥入利得（以下利得と略す）と子音 明瞙度の関係を検討したので報告する。

2. 対象打よび方法

1991年 6 月より1992年 1 月までの8 ケ月間に当科で適合した補聴器を1ケ月以上装用し 自覚的に良好な補聴が得られた感音難聴症例のうち、以下に述べる検査で補聴器装用に伴 5明瞭度の改善率が $15 \%$ 以上を示した感音難㯖症例 38 名を対象とした。対象は裸耳の最高 語音明瞭度が70\%以上でレタルートメント現象隄性を示した症例に限定した（表 $1 ， 2$ )。

裸耳お上び補聴器装用時の聴力域值と明嘹度の測定は、防音室内にてスピーカーを用い 自由音場で施行した。スピーカーは被検者の前方5 $0 \mathrm{~cm}$ のころに設定し、音生はあらかじ めレベルメーターで皎正した。補聴器の選択と適合に特別な基準は設けず被検者が日常生 活で最も聞きやすいレベルに設定した。方法はまずウァーブルトーンを用いて $250 \mathrm{~Hz} \sim 6000$ $\mathrm{Hz}$ での裸耳および補聴器装用時の聴力域值を測定し利得を求めた。次に検查語音を測定耳 の平均聴力レベル $+10 \mathrm{~dB}$ に設定し、裸耳と補聴器装用時の 明瞭度検查を行った。明瞭度検查は67式語表を用いて数分 の間隔をおいて2回施行し、2 回の結果を総合して明瞭度 と子音異聴の改善率を求めた。子音は有声子音、鼻音群と 無声子音群の2 群に分けて明瞭度を求め、補聴器装用によ り異聴が $15 \%$ 以上改善した症例を改善例と判定し利得との 関係を検討した。

3. 結 果

明瞭度の改善率は、38名中 30 名 $(79 \%)$ が $30 \%$ 以下であり 比較的低值であった（表 3 )。利得と子音異喵の関倸は、 $1500 \mathrm{~Hz}$ の利得々有声子音、鼻音群、 $3000 \mathrm{~Hz} 、 4000 \mathrm{~Hz}$ の利 得と艏声子音群の改善例の比率が相関する傾向を認めた(表 $4,5,6)$ 。

4. 考案

・補聼器を装用する目的として会話の語尾の聞き取りに影

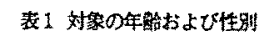

\begin{tabular}{|c|c|c|c|}
\hline 年䑪 & 男 & 女 & 計 \\
\hline $10-50$ & 3 & 1 & 4 \\
\hline $51-60$ & 1 & 2 & 3 \\
\hline $61-70$ & 4 & 4 & 8 \\
\hline $71-80$ & 7 & 9 & 16 \\
\hline $81-$ & 4 & 3 & 7 \\
\hline 㖕 & 19 & 19 & 388 \\
\hline
\end{tabular}

篝する子音明瞭度の改善があげられるが、補聴器装用に伴 
う子音異聴の変化につんての報告は少ない。そこで今回は補聴器 が日常生活に適合した感音難聴症例を対象として利得と子音明瞭 度の関係を検討した。補聴器適合検査の際に用いる検查語表は特 に子音明瞭度の検討を行う場合語数の多い57式語表が一般的であ るが ${ }^{2)} 、 今$ 回の対象は高齢者が多く50語を連続して行う57式語表

\section{表3 語音明眰度の改善垶}

\begin{tabular}{cl}
\hline 改等率 $(\%)$ & 症例数 \\
$15-20$ & 16 名 \\
$21-30$ & 14 \\
$31-40$ & 6 \\
$41-50$ & 2
\end{tabular}
では検査後半に疲労のため明瞭度が低下する症例がみられたため、 試みとして語数の少ない 67 式語表を 2 回施行しこれを総合して明瞭度を求め た。利得と子音明瞭度の関係は、無声 子音群では $3000 \mathrm{~Hz} 、 4000 \mathrm{~Hz}$ の 2 つの周 波数の利得と相関したが、有声子音、 鼻音群では $1500 \mathrm{~Hz}$ の利得以外とclear な相関は認められなかった。有声子音、 鼻音群の明膫度に関してまず低音域に つんては利得が $5 \mathrm{~dB}$ 以内の症例が 250 $\mathrm{Hz}$ は23名、 $500 \mathrm{~Hz}$ は13名ありこのうち $70 \%$ 以上の症例が改善を示しており関 与は低んと思われる。次に中音域の 1500 $\mathrm{Hz}$ 以外の周波数につんては $30 \mathrm{~dB}$ 以上の 利得を認めた症例では $80 \%$ 以上が改善 を示したこと、低音域に比べ利得が 5 $\mathrm{dB}$ 以内の症例は少なんことより関与し ている可能性は否定できない。種々の 有声子音、鼻音の明瞭度が $1500 \mathrm{~Hz}$ の利 得のみと相関することは考えにくく、 $1500 \mathrm{~Hz}$ をどークとして $750 \mathrm{~Hz}$ から 2000 $\mathrm{Hz}$ までの広ん周波数帯域が異聴の改善 に関与しているものと推測される。

表 4 低音域の実耳捚入利得と有声子音、童群の 異㯖改善例

\begin{tabular}{ccc}
\hline 実耳㨉入利得 & \multicolumn{2}{c}{ 改善例 $/$ 対象 } \\
& $250 \mathrm{~Hz}$ & $500 \mathrm{~Hz}$ \\
$0-5(\mathrm{~dB})$ & $16 / 23(70 \%)$ & $10 / 13(77 \%)$ \\
$10-15$ & $8 / 10(80)$ & $10 / 17(59)$ \\
$20-25$ & $2 / 5(40)$ & $5 / 7(70)$ \\
$30-35$ & & $1 / 1(100)$ \\
$40-45$ & \\
\hline 計
\end{tabular}

表 5 中音域の実耳㨉入利得と有声子音、章音群の異㮦改善例

\begin{tabular}{|c|c|c|c|c|}
\hline \multirow{2}{*}{\multicolumn{2}{|c|}{ 実耳捚入利得 }} & \multicolumn{2}{|c|}{ 改善例／対象 } & \multirow[b]{2}{*}{$2000 \mathrm{~Hz}$} \\
\hline & $750 \mathrm{~Hz}$ & $1000 \mathrm{H}_{2}$ & $1500 \mathrm{flz}$ & \\
\hline $0-5(\mathrm{~dB})$ & $2 / 5(40 \%)$ & $1 / 1(100 \%)$ & & $1 / 1(100 \%$ \\
\hline $10-15$ & $15 / 20(75$ & $12 / 15(80)$ & $7 / 14(50 \%)$ & $10 / 15(67$ \\
\hline $20-25$ & $5 / 9(56$ & $10 / 19(53$ & $15 / 20(75$ & $11 / 1765$ \\
\hline $30-35$ & $100)$ & $3 / 3(100$ & $4 /$ & $4 / 5(80$ \\
\hline
\end{tabular}

表6 高音㖪の実耳括入利得と無声子音群の異㯖改善例

\begin{tabular}{|c|c|c|c|}
\hline & \multicolumn{2}{|l|}{ 放善例/対象 } \\
\hline \multicolumn{2}{|c|}{ 実耳㨉入利得 } & $4000 \mathrm{~Hz}$ & $6000 \mathrm{~Hz}$ \\
\hline $0-5(\mathrm{~dB})$ & $0 / 1(0 \%)$ & $0 / 1(0 \%)$ & $12 / 19(63 \%)$ \\
\hline $10-15$ & $12 / 20(60)$ & $12 / 20(60)$ & $11 / 13(85$ \\
\hline $20-25$ & $11 / 13(85$ & $10 / 12(83$ & $3 / 5(60$ \\
\hline $30-35$ & $4 / 4(100)$ & $5 / 5(100)$ & $1 / 1(100$ \\
\hline
\end{tabular}

5. まとめ

補聴効果がみられた感音難聴症例を対象として、利得と子音明瞭度の関係を検討した。 その結果 $1500 \mathrm{~Hz}$ の利得と有声子音、鼻音群、 $3000 \mathrm{~Hz} 、 4000 \mathrm{~Hz}$ の利得と無声子音群の異聴改 善率が相関する傾向を認めたが、今後は症例数を增やし検查方法も含めさらに検討を加え る必要がある。

参考文献

1.中村賢二他：補聴器装用マニュアル。：85-119，1984.

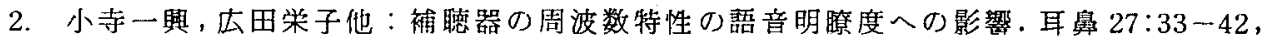
1981 .

3. Elmer, O. and Martha, B. : Consonant phonemic errors associated wi th pure tone configurations and certain kinds of hearing impairment. Journal of Speech and Hearing Research, 15:308-322. 1972. 